Pacific Journal of Mathematics 


\title{
SUBADDITIVE FUNCTIONS
}

\section{ChI Song Wong}

\begin{abstract}
In a recent paper, D. W. Boyd and J. S. W. Wong ask for an example of positive subadditive function $\phi$ for which $\phi(t)<t$ for all $t$ and there exist $0<c<d$ such that $\sup _{t \varepsilon[c, d]} \phi(t) / t=1$. Our main result is that such an example does not exist.
\end{abstract}

For a metric space $(X, d)$, we shall use Ran $d$ to denote the set $\{d(x, y): x, y \in X\}$ and use $c l$ Ran $d$ to denote the closure of Ran $d$. Let $X$ be a complete metric space, let $\psi$ be a function of $c l$ Ran $d$ into $[0, \infty)$ and let $T$ be a function of $X$ into itself such that $T$ is $\psi$-contractive on $X(d(T(x), T(y)) \leqq \psi(d(x, y)), x, y \in X)$. E. Rakotch [3, Corollary to Theorem 2] shows that if there is a decreasing function $\alpha$ on $[0, \infty)$ such that for any $t>0, \alpha(t)<1$ and $\psi(t)=\alpha(t) t$, then $T$ has a unique fixed point. In order to show that Theorem 2 in [1] actually extends the above result when $X$ is metrically convex, D. W. Boyd and J. S. W. Wong [1, p. 464] ask for an example of positive subadditive function $\phi$ for which $\phi(t)<t$ for all $t>0$ and there exist $0<c<d$ such that

$$
\sup _{t \in[c, d]} \phi(t) / t=1 \text {. }
$$

We now show that such an example does not exist.

THEOREM. Let $\phi$ be a positive subadditive function on an interval $(0, b)(0<b \leqq \infty)$ such that $\phi(t)<t$ for all $t$ in $(0, b)$. Then

$$
\sup _{a \leqq t<b} \phi(t) / t<1, \quad 0<a<b .
$$

Proof. If $b=\infty$, then by subadditivity and Theorem 7.6.2 in [2],

$$
\lim _{t \rightarrow \infty} \phi(t) / t=\inf _{t>0} \phi(t) / t ;
$$

thus from $\phi(t) / t<1, \sup _{t>a} \phi(t) / t<1$ for large $a$ 's. So we may assume that $b<\infty$. Suppose to the contrary that there exist $c, d$ in $(0, b)$ such that $c<d$ and

$$
\sup _{t \in[c, d]} \phi(t) / t=1 .
$$

Then there exists a sequence $\left\{t_{n}\right\}$ in $[c, d]$ such that

$$
\lim _{n \rightarrow \infty} \phi\left(t_{n}\right) / t_{n}=1 \text {. }
$$


By compactness of $[c, d]$, we may, by taking a subsequence, assume that $\left\{t_{n}\right\}$ converges to some $t$ in $[c, d]$. Let $m$ be any positive integer. Then by the subadditivity of $\phi$,

$$
\phi\left(t_{n}\right) \leqq m \phi\left(t_{n} / m\right)<t_{n}
$$$$
n \geqq 1 \text {. }
$$

From (1) and (2),

$$
\lim _{n \rightarrow \infty} \phi\left(t_{n} / m\right)=t / m \text {. }
$$

We now prove by induction that

$$
\lim _{n \rightarrow \infty} \phi\left(j t_{n} / 2^{k}\right)=j t / 2^{k}, \quad k \geqq 1,0<j<2^{k}, j \text { is odd. }
$$

Assume that (4) is true for $k \leqq i$, where $i$ is given. Let $j$ be any odd number in $\left(0,2^{i+1}\right)$. Then

$$
\phi\left((j+1) t_{n} / 2^{i+1}\right) \leqq \phi\left(j t_{n} / 2^{i+1}\right)+\phi\left(t_{n} / 2^{i+1}\right)<(j+1) t_{n} / 2^{i+1}
$$

By (5), the induction hypothesis and (3) (also by (1) if $\left.j=\left(2^{i+1}-1\right) / 2^{i+1}\right)$, we have by letting $n \rightarrow \infty$,

$$
(j+1) t / 2^{i+1} \leqq \lim _{n \rightarrow \infty} \sup \phi\left(j t_{n} / 2^{i+1}\right)+t / 2^{i+1} \leqq(j+1) t / \wedge^{i+1}
$$

i.e.,

$$
\lim _{n \rightarrow \infty} \phi\left(j t_{n} / 2^{i+1}\right)=j t / 2^{i+1},
$$

proving (4). Take any $s$ in $(0, t)$. It suffices to prove that $s \leqq \phi(s)$. Since the set

$$
D=\left\{j t / 2^{k}: k \geqq 1,0<j<2^{k}, j \text { is odd }\right\}
$$

is dense in $(0, t)$, there exists a strictly decreasing sequence $\left\{s_{n}\right\}$ in $D$ which converges to $s$. By (4), there is a sequence $\left\{w_{n}\right\}$ for which

$$
s_{n}-1 / n<w_{n}<s_{n}, \phi\left(w_{n}\right)>s_{n}-1 / n, \quad n \geqq 1 .
$$

Now

$$
\phi\left(w_{n}\right) \leqq \phi\left(w_{n}-s\right)+\phi(s)<\left(w_{n}-s\right)+\phi(s), \quad n \geqq 1 .
$$

From (6) and (7), we obtain $s \leqq \phi(s)$.

From the above result, we know that the condition (24) in [1] can be dropped. We thus have an improved version of [1, Proposition].

Proposition. Let $(X, d)$ be a complete metrically convex metric space and let $f: X \rightarrow X$. Suppose that there is a function $\psi$ of $c l$ Ran $d$ into $[0, \infty)$ such that $\psi(t)<t$ for all $t$ in $c l \operatorname{Ran} d-\{0\}$ and $f$ is $\psi$ contractive on $X$. Then there exists a decreasing function $\alpha$ on $[0, \infty)$ 
such that $\alpha(t)<1$ for all $t>0$ and

$$
d(f(x), f(y)) \leqq \alpha(d(x, y)) d(x, y), \quad x, y \in X .
$$

D. W. Boyd and J. S. Wong show that $\alpha$ in the above proposition can actually be constructed as follows:

$$
\alpha(t)=\sup _{s \geqq t} \phi(s) / s, \quad t>0,
$$

where

$$
\phi(t)=\sup \{d(f(x), f(y)): x, y \in X, d(x, y)=t\}, \quad t \in \operatorname{Ran} d
$$

\section{REFERENCES}

1. D. W. Boyd and J. S. Wong, On nonlinear contractions, Amer. Math. Soc., 20 (1969), 458-464.

2. E. Hille and R. S. Phillips, Functional analysis and semi-groups, Amer. Math. Soc. Colloq. Publ., Vol. 31, Amer. Math. Soc., Providence, R. I., 1957.

3. E. Rakotch, A note on contraction mappings, Proc. Amer. Math. Soc. 13 (1962), 459-465.

Received July 27, 1970.

SOUthern IllinoIS UNIVERSity 



\section{PACIFIC JOURNAL OF MATHEMATICS}

\section{EDITORS}

H. SAMELson

Stanford University

Stanford, California 94305

R. R. PHelPS

University of Washington

Seattle, Washington 98105
J. Dugundu

Department of Mathematics

University of Southern Californle

Los Angeles, California 9.0007

RICHARD ARENS

University of California

Los Angeles, California 9.0024

\section{ASSOCIATE EDITORS}
E. F. BECKENBACH
B. H. NeumanN
F. WOLE
K. Yoshida

\section{SUPPORTING INSTITUTIONS}

UNIVERSITY OF BRITISH COLUMBIA

CALIFORNIA INSTITUTE OF TECHNOLOGY

UNIVERSITY OF CALIFORNIA

MONTANA STATE UNIVERSITY

UNIVERSITY OF NEVADA

NEW MEXICO STATE UNIVERSITY

OREGON STATE UNIVERSITY

UNIVERSITY OF OREGON

OSAKA UNIVERSITY

UNIVERSITY OF SOUTHERN CALIFORNIA

\author{
STANFORD UNIVERSITY \\ UNIVERSITY OF TOKYO \\ UNIVERSITY OF UTAH \\ WASHINGTON STATE UNIVERSITY \\ UNIVERSITY OF WASHINGTON \\ AMERICAN MATHEMATICAL SOCIETY \\ CHEVRON RESEARCH CORPORATION \\ NAVAL WEAPONS CENTER
}

The Supporting Institutions listed above contribute to the cost of publication of this Journal, but they are not owners or publishers and have no responsibility for its content or policies.

Mathematical papers intended for publication in the Pacific Journal of Mathematics should be in typed form or offset-reproduced, (not dittoed), double spaced with large margins. Underline Greek letters in red, German in green, and script in blue. The first paragraph or two must be capable of being used separately as a synopsis of the entire paper. The editorial "we" must not be used in the synopsis, and items of the bibliography should not be cited there unless absolutely necessary, in which case they must be identified by author and Journal, rather than by item number. Manuscripts, in duplicate if possible, may be sent to any one of the four editors. Please classify according to the scheme of Math. Rev. Index to Vol. 39. All other communications to the editors should be addressed to the managing editor, Richard Arens, University of California, Los Angeles, California, 90024.

50 reprints are provided free for each article; additional copies may be obtained at cost in multiples of 50 .

The Pacific Journal of Mathematics is published monthly. Effective with Volume 16 the price per volume (3 numbers) is $\$ 8.00$; single issues, $\$ 3.00$. Special price for current issues to individual faculty members of supporting institutions and to individual members of the American Mathematical Society: $\$ 4.00$ per volume; single issues $\$ 1.50$. Back numbers are available.

Subscriptions, orders for back numbers, and changes of address should be sent to Pacific Journal of Mathematics, 103 Highland Boulevard, Berkeley, California, 94708.

PUBLISHED BY PACIFIC JOURNAL OF MATHEMATICS, A NON-PROFIT CORPORATION

Printed at Kokusai Bunken Insatsusha (International Academic Printing Co., Ltd.), 7-17, Fujimi 2-chome, Chiyoda-ku, Tokyo, Japan. 


\section{Pacific Journal of Mathematics}

\section{Vol. 36, No. 2 December, 1971}

George E. Andrews, On a partition problem of H. L. Alder ............ 279

Thomas Craig Brown, An interesting combinatorial method in the theory of locally finite semigroups .......................... 285

Yuen-Kwok Chan, A constructive proof of Sard's theorem ............. 291

Charles Vernon Coffman, Spectral theory of monotone Hammerstein

operators...................................... 303

Edward Dewey Davis, Regular sequences and minimal bases .......... 323

Israel (Yitzchak) Nathan Herstein and Lance W. Small, Regular elements in

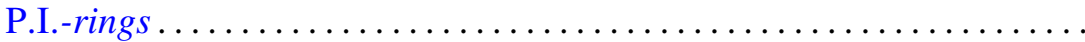

Marcel Herzog, Intersections of nilpotent Hall subgroups ..............

W. N. Hudson, Volterra transformations of the Wiener measure on the space

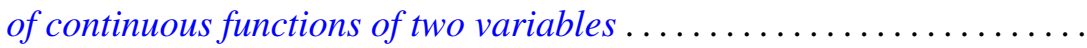

J. H. V. Hunt, An n-arc theorem for Peano spaces ................ 351

Arnold Joseph Insel, A decomposition theorem for topological group

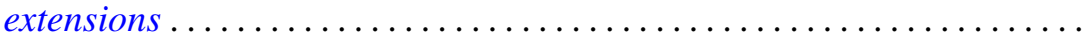

Caulton Lee Irwin, Inverting operators for singular boundary value

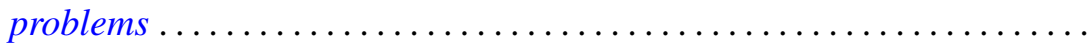

Abraham A. Klein, Matrix rings of finite degree of nilpotency ............ 387

Wei-Eihn Kuan, On the hyperplane section through a rational point of an algebraic variety...

John Hathway Lindsey, II, On a six-dimensional projective representation of $\mathrm{PSU}_{4}(3)$

Jorge Martinez, Approximation by archimedean lattice cones ...

J. F. McClendon, On stable fiber space obstructions .........

Mitsuru Nakai and Leo Sario, Behavior of Green lines at the Kuramochi boundary of a Riemann surface ....................

Donald Steven Passman, Linear identities in group rings. I. .

Donald Steven Passman, Linear identities in group rings. II ...

David S. Promislow, The Kakutani theorem for tensor products of

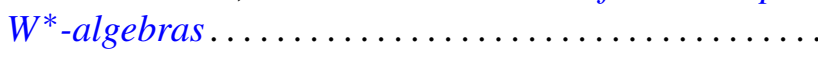

Richard Lewis Roth, On the conjugating representation of a finite group

Bert Alan Taylor, On weighted polynomial approximation of entire functions...

William Charles Waterhouse, Divisor classes in pseudo Galois

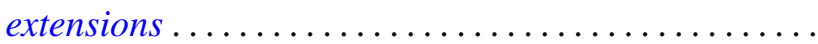

Chi Song Wong, Subadditive functions ...

Ta-Sun $\mathrm{Wu}$, A note on the minimality of certain bitransformation groups 